\title{
THE EXTENT OF MARITIME TERRORISM AND PIRACY: A COMPARATIVE ANALYSIS
}

\author{
Lydelle Joubert ${ }^{1}$
}

\begin{abstract}
Political and socio-economic factors led to the resurrection of piracy during the 1970s. By 1983, the problem became alarming, leading to the adoption of antipiracy measures by the international community. During the same period, maritime terrorist attacks increased, although incidents remained localised. As insurgent movements fought on land to gain independence from former colonial governments, terrorist actions spilled into the maritime domain. The attacks on the USS Cole in 2000 and on the French-registered oil tanker, Limburg, in 2002 coupled with the terrorist attacks on the United States of America (US) on 11 September 2001 (9/11), created fear that a captured ship could be used as a delivery platform for weapons of mass destruction (WMD) or that a ship with dangerous cargo could be used as a weapon. No exclusively maritime terrorist organisations exist today. Maritime terrorism is only one of the areas of operation for terrorist organisations. Links between maritime pirates and terrorists are also limited, as the objectives of these organisations differ. Pirates have financial motives, while terrorists have political motives. Although cooperation between these groups is unlikely, it is not impossible and could be dangerous especially in vulnerable areas such as the coast of Somalia, the Red Sea and the Gulf of Aden.
\end{abstract}

\section{Introduction}

Eighty per cent of the world's cargo is carried by sea on more than 112000 ships manned by more than 1,5 million seafarers, and as the maritime domain is an unregulated area, ships and crew on these ships are vulnerable to maritime violence. ${ }^{2}$ Thousands of ports and harbour facilities serviced by hundreds of thousands of port staff are also vulnerable to maritime criminals and terrorists. Attacks by terrorists, pirates and criminals operating in the maritime environment also have the potential

Scientia Militaria, South African Journal of Military Studies, Vol 41, Nr 1, 2013, pp. 111-137. doi: $10.5787 / 41-1-1055$ to affect global trade.

Motive determines whether an incident will be classified as an act of piracy or as an act of terrorism. These motives are 
financial or material gain in the case of piracy, and political gain in the case of terrorism. For this reason, pirates and terrorists seldom cooperate in launching maritime attacks. In comparing maritime terrorism and piracy, several other factors than motive will be investigated. Factors such as the choice of target, tactics and the use of violence will differ between maritime terrorism and piracy because of the motives behind the actions. Other factors will display similarities as both groups operate in the maritime domain using boats or ships in their operations, although the choice of vessels may differ and may be determined by the type of operation. In both cases, the socio-economic and political conditions in the host countries will contribute to the existence of maritime terrorism and piracy, and both groups will operate from a land base.

As a result of the terrorist attacks on the US on 11 September 2001, maritime piracy and terrorism were increasingly linked and became highly controversial subjects. Countries fear that a captured ship could be used as a delivery platform for WMD or that a ship with dangerous cargo itself could be used as a weapon. Many questions however remain. It could be asked whether enough similarities exist to link piracy and maritime terrorism. This article will give an overview of the historical and current extent of maritime piracy, armed robbery of ships and maritime terrorism and will proceed to investigate similarities, differences and connections between pirates and terrorists operating in the maritime domain and the likelihood of cooperation between these groups.

In order to distinguish between piracy, acts of armed robbery of ships and maritime terrorism it is necessary to define these concepts and identify the origins of these definitions.

\section{The Concept of Maritime Terrorism, Piracy and Armed Robbery of Ships}

Both the United Nations (UN)'s International Maritime Organization (IMO) and the International Maritime Bureau (IMB) currently use the definition of piracy as described in the United Nations Convention on the Law of the Sea (UNCLOS).

$\mathrm{UNCLOS}^{3}$ defines piracy as:

(a) Any illegal acts of violence or detention, or any act of depredation, committed for private ends by the crew or the passengers of a private ship or a private aircraft, and directed: 
(i) on the high seas, against another ship or aircraft, or against persons or property on board such ship or aircraft;

(ii) against a ship, aircraft, persons or property in a place outside the jurisdiction of any State;

(b) any act of voluntary participation in the operation of a ship or of an aircraft with knowledge of facts making it a pirate ship or aircraft; and

(c) any act of inciting or of intentionally facilitating an act described in subparagraph (a) or (b).

According to this definition, piracy is limited to acts outside the jurisdiction of the coastal waters of a state. Acts committed in coastal waters are considered armed robbery. This means that many cases of violence against ships occurring in the territorial waters of states are excluded from this definition. This also excludes acts of maritime terrorism, as political objectives are not included in this definition. ${ }^{4}$

Armed robbery of ships is defined by Resolution A 1025 (26) as:

- Any unlawful act of violence or detention or any act of depredation, or threat thereof, other than an act of piracy, committed for private ends and directed against a ship or against persons or property on board such ship, within a State's internal waters, archipelagic waters and territorial sea;

- Any act of inciting or of intentionally facilitating an act described above. ${ }^{5}$

According to Ranstorp and Wilkinson, ${ }^{6}$ terrorism is defined as

... the systematic use of coercive intimidation usually, though not exclusively, to service political ends. It is used to create and exploit a climate of fear among a wider group than the immediate victims of the violence, often to publicise a cause, as well as to coerce a target into acceding to terrorist aims.

The maritime environment is only one of the areas of operations where terrorists use coercion to further their political aims.

Maritime terrorism has no internationally agreed upon definition. Legal scholars have agreed on an operational definition for maritime terrorism based on Articles 3 and 4 of the 1988 Convention for the Suppression of Unlawful Acts against the Safety of Maritime Navigation (SUA), even though the SUA Convention does not refer to terrorism specifically. Maritime terrorism is defined as: 
- Any attempt or threat to seize control of a ship by force;

- To damage or destroy a ship or its cargo;

- To injure or kill a person on board a ship; or

- To endanger in any way the safe navigation of a ship that moves from the territorial waters of one State into those of another State or into international waters. $^{7}$

The Maritime Co-operation Working Group of the Council for Security and Co-operation in the Asia-Pacific (CSCAP) focuses its definition on terrorism:

- Within the marine environment;

- Used against vessels or fixed platforms at sea or in port, or against any one of their passengers or personnel; and

- Against coastal facilities or settlements, including tourist resorts. ${ }^{8}$

For statistical purposes, the IMB does not distinguish between piracy, armed robbery of ships or maritime terrorism. ${ }^{9}$ As IMB statistics were used in this study, no distinction is made between piracy and armed robbery of ships when referring to statistics.

Piracy was almost eliminated by the end of the $19^{\text {th }}$ century, but increased again in the 1970s and 1980s. In many Third World countries, this period was known for liberation wars against former colonial governments. Many of these wars had a maritime dimension and as result, several maritime terrorist attacks were recorded.

\section{Piracy, Armed Robbery of Ships and Maritime Terrorism in the Twentieth Century}

During the twentieth century, incidents of piracy and acts of armed robbery of ships were the highest in Southeast Asia and Malacca, the Far East, India, Bangladesh, the west and east coasts of Africa, the Caribbean, and the US. By 1983, the problem of piracy and acts of armed robbery of ships became alarming. ${ }^{10}$ Since then, a steady increase in incidents occurred, with a total of 1256 incidents of armed robbery of ships and piracy reported since the beginning of 1994 to the end of 1999. ${ }^{11}$ The end of the Cold War brought an end to worldwide patrols by the then superpowers, the US and the Union of Soviet Socialist Republics (USSR), which contributed to the rise in piracy after the $1990 \mathrm{~s} .{ }^{12}$ Incidents of maritime terrorism were higher in the last half on the twentieth century compared to incidents after 
2000. A total of 121 incidents of maritime terrorism were reported from 1968 to the end of $1999 .{ }^{13}$

\section{Extent, Causes and Consequences of Piracy and Armed Robbery of Ships in the Twentieth Century}

During the twentieth century, an increase in incidents of maritime piracy and acts of armed robbery of ships in specific regions could usually be explained by conflict in the region, an absence of crime-fighting institutions or strong navies to counter piracy and acts of armed robbery of ships, or a change in socio-economic conditions in the country or region affected. ${ }^{14}$

Southeast Asia and the South China Sea

During 1979, more than 200000 refugees fled Indo-China through the South China Sea to reach Southeast Asian countries after the communist takeover of South Vietnam in 1975, and Vietnam's subsequent attack on Kampuchea (Cambodia) in 1979, which created a refugee crisis. These refugees became known as the "boat people". Over the next few years, more than 600000 people fled Indo-China and an estimated 60000 to 250000 people died as a result of natural causes, bad weather and piracy. Many Thai fishermen turned to piracy, attacking refugees from South Vietnam and Kampuchea. An estimated three per cent of refugees suffered attacks. ${ }^{15}$ According to Refugee Reports for the period 1981 to 1988 , a total of 884 piracy incidents and acts of armed robbery of ships occurred over this period, often including murder, abduction and rape. Not all attacks in the South China Sea were refugee-related. In 1993, incidents of piracy and acts of armed robbery of ships in the South China Seas rose to 42 incidents out of 67 incidents worldwide. ${ }^{16}$

As a direct result of the refugee crisis in Asia, the United Nations High Commission for Refugees (UNHCR) took the lead in initiatives to reduce incidents of piracy in 1982, when internationally funded anti-piracy patrols were established in the Gulf of Thailand. An appeal was made to merchant vessels to rescue refugees in distress at sea. In 1984, only nine per cent of the boat people were rescued at sea, often being passed by ships. A regional information centre was also established in Kuala Lumpur, Malaysia to monitor piracy incidents in the area. ${ }^{17}$

About seven cases of piracy and acts of armed robbery of ships occurred in the Malacca Straits annually before 1989. In 1989, 28 incidents were reported, which increased to 50 by 1991 . In 1992, the IMO initiated a working group from the 
three littoral States of the Malacca Straits (Indonesia, Malaysia and Singapore) as well as seven others, to investigate the problem in the Malacca Straits and to recommend preventative measures in dealing with piracy and armed robbery of ships specifically in the straits but also in other areas affected by the problem. ${ }^{18}$ As a result of the recommendations of the Working Group, a resolution (A.738(18)) was adopted in 1993 by the IMO. The new resolution recommended that masters of ships should immediately report attacks or threats of attack to the nearest rescue and coordination centre and request such co-ordination centres to warn shipping in the immediate vicinity of the attack immediately. Local security forces must also be notified in order for them to react to any such incidents. As a result of these initiatives only 16 attacks were reported between 1993 and 1999. This success was however short lived as piracy in the straits rose to an alarming level in 2000.

Maritime Piracy in Africa

Since the 1970s, Nigeria experienced a huge increase in the volume of imports due to the oil boom. During the 1980s, West Africa had the highest number of reported incidents (approximately 25 reports annually) of piracy and armed robbery of ships in the world. ${ }^{19}$ By 1980, Lagos was the world's worst affected harbour. Between 1982 and 1986, roll-on roll-off (RORO) vessels and container ships, waiting for weeks and months to enter inadequate harbours in order to offload goods (known as the "cement armada") were attacked. ${ }^{20}$ Between 1984 and 1985, Nigerian authorities acted against piracy bases and outlets of the stolen goods by increasing patrols and surveillance, ${ }^{21}$ resulting in a dramatic reduction in acts of armed robbery of ships in 1986 in the ports of Lagos and Bonny. ${ }^{22}$ Attacks on ships rose dramatically again since 1999, due to attacks by the Movement for the Emancipation of the Niger Delta (MEND) on predominately workers in the oil industry.

An attack in 1991 and three attacks that occurred in Sierra Leone between 1996 and 1999 could be linked to circumstances created during the civil war in Sierra Leone (1991 to 2002) that temporarily ousted President Ahmad Tejan Kabbah. During the same period, attacks took place in the coastal waters or off the coast of most West African countries and ranged from theft in harbours and anchorages to attacks with speedboats using automatic weapons. ${ }^{23}$

By 1998, two thirds of all worldwide maritime abductions took place in the Gulf of Aden, and yacht hijackings occurred in the Gulf of Aden and the Red Sea. 
Incidents in 1995 and 1996 were related to the dispute between Yemen and Eritrea over the Hanish Islands in the Southern Red Sea. ${ }^{24}$

The Americas and Caribbean

After 1971, a sharp increase in yacht hijackings used in drug smuggling was experienced in the Southeastern Atlantic, the Gulf of Mexico, along the Pacific Coast and Hawaii. None of the yacht owners were ever found and the yachts were destroyed after the drugs had been transported to the intended destination. This was as a direct result of the dismantling of professional drug rings by drug enforcement agencies in the late 1970s. The vacuum thus created was filled by amateur operators from South and Central America, and it is estimated that 44 yachts were hijacked in this manner between 1971 and $1974 .^{25}$ Between 1981 and 1985, there were 30 reported acts of armed robbery of ships around Santos, Brazil. ${ }^{26}$ In the early 1990s, acts of armed robbery of ships and piracy occurred in the West Indies, Costa Rica, Ecuador, Colombia and Brazil, with the Rio de Janeiro and Santos ports being the most dangerous in this area. ${ }^{27}$

Between 1970 and 1989, the US was affected by acts of piracy and armed robbery of ships in several ways. Cruise ship extortion took place in the 1970s and 1980s during which ransom was extorted by threatening explosions on board ships or hijackings of ships. Mutinies over labour disputes as well as government marine scams also took place over this time. An example of this type of scam was the attempted hijacking in 1978 of the USS Trepang, a nuclear-powered submarine armed with nuclear-tipped ballistic missiles. One of the hijackers involved was a former crew member of the submarine. The plan was to blow up the submarine's tender or service boat, take over the submarine, kill the crew, sail to New London, Connecticut, fire a nuclear missile at an American East Coast city and make certain demands. The submarine was also to be sold to an unidentified buyer. An undercover Federal Bureau of Investigation (FBI) agent uncovered the plot. It was not clear whether the aim was in fact to steal the submarine or to steal the front money. ${ }^{28}$

\section{Extent, Causes and Consequences of Maritime Terrorism in the Twentieth Century}

Incidents of maritime terrorism were high in the second half of the $20^{\text {th }}$ century. Between 1979 and 1989, 47 terrorist attacks on ships were reported. ${ }^{29}$ During these incidents, eight vessels were hijacked and 11 ships were destroyed. 
Passenger liners were specifically targeted during maritime terrorism attacks due to the publicity value of such attacks. Although the hijacking of the Santa Maria in 1961 was the first such case in the $20^{\text {th }}$ century, the Achille Lauro incident in 1985 created far-reaching publicity and influenced international relations.

The Santa Maria Hijacking

The Santa Maria hijacking in 1961 is regarded as the first incident of modern maritime terrorism. The hijacking internationalised conditions in Portugal's colonies in Africa and as a result, Angola was placed on the UN Security Council's agenda in 1961. The hijacking also sparked the 1961 uprising in Angola. ${ }^{30}$

The Santa Maria was hijacked by Colonel Galvao and 24 Portuguese insurgents. Galvao claimed to represent the Portuguese National Independence Movement, which aimed to overthrow the government of President Salazar in Angola. The terrorists came on board as passengers, killing an officer in the process and wounding another crew member. British, US, Danish and Portuguese warships were involved in the search for the ship on the high seas. US and Portuguese naval forces attempted to intercept the ship and cut off its escape to Angola. As the motives were political in nature, the incident could not be regarded as an act of piracy and US forces were unable to board the ship on legal grounds. Negotiations followed and the passengers as well as Galvao and the insurgents disembarked in Brazil - the latter after having been granted asylum. ${ }^{31}$ Problems cropped up during the handling of the case in international law as the incident could not be defined as an act of piracy because of the political nature of the incident, the two-ship requirement for an incident to be labelled an act of piracy as well as the fact that the terrorists came aboard while the ship was moored and did not board in international waters. $^{32}$

Palestinian Terrorist Organisations and the Achille Lauro Hijacking

Palestinians were involved in maritime terrorism in the role of attackers (six cases between 1971 and 1985) as well as victims, usually involving Israeli or rival forces. $^{33}$ One of these incidents was the hijacking of the Achille Lauro. On 7 October 1985, the cruise liner Achille Lauro, with more than 750 passengers and 331 crew members on board, made a stop at Alexandra, where 651 of the passengers disembarked, planning to meet the ship again in Port Said. ${ }^{34}$ Soon after leaving Alexandria, four members of the Palestine Liberation Front (PLF) hijacked the ship. The hijackers demanded that the ship sail to Syria, but Syrian authorities did not 
grant the ship permission to enter port. The terrorists killed Leon Klinghoffer, a wheelchair-bound elderly Jewish-American passenger and threw his body overboard. Yasser Arafat, the head of the Palestine Liberation Organisation (PLO), declared that his organisation was not involved in the incident and offered to help broker the release of the hostages. One of the men sent to Egypt as part of the negotiating team, Abul Abbas, however, turned out to be the master brain behind the hijacking. ${ }^{35}$

The ship sailed on to Port Said where the Egyptian government granted the members of the PLF safe passage out of Egypt in return for the hostages and the ship. US Navy F-14 fighter planes forced the EgyptAir Boeing 737 aircraft transporting the hijackers to Tunis, Tunisia to land at the US-Italian base in Sicily where the hijackers were arrested by the Italian authorities. Abbas was, however, allowed to leave the country despite a US request to arrest him, which strained USItalian relations. ${ }^{36}$ This led to the temporary collapse of the Italian government on 17 October 1985 when the Craxi government split over the handling of Abbas and the hijacking. Relations between the US and Egypt were also strained due to the hijacking of the EgyptAir plane which Egyptians saw as an insult to their national honour and an act of air piracy. US forces in Baghdad eventually arrested Abbas in $2003 .^{37}$

The hijacking of the Achille Lauro had far-reaching implications for the international cruise line industry, international law and the domestic law of countries such as the US. In November 1985, the IMO's 14th Assembly adopted a resolution: measures to prevent unlawful acts, which threaten the safety of ships and the security of their passengers and crew. ${ }^{38}$ In November 1986, a convention for the suppression of unlawful acts against the safety of maritime navigation was proposed, the SUA Convention. Unlawful acts stipulated by the SUA Convention are the seizure of ships by force, violence against persons on board ships, and placement of devices on board a ship with the intent to destroy or damage it.

Maritime Terrorism in Africa

Two organisations were involved in maritime terrorism incidents in Africa, namely the Polisario Front in Morocco and Mauritania, and the Somali National Movement in Somalia. Between 1978 and 1987, about 17 attacks on mostly fishing boats off the coast of Morocco and Mauritania were attributed to the Polisario Front. The Polisario Front was fighting for the independence of the Saharan (Sahrawi) Arab Democratic Republic or Spanish Sahara. Attacks were launched from Zodiac- 
type motorised boats with machine guns or light armour-piercing missiles. In some cases, crews of the stricken vessels were held for ransom. ${ }^{39}$ In 1989, the Somali National Movement seized ships trading with the Siad Barre dictatorship in Somalia in the name of the Somali National Movement Coast Guard in a bid to overthrow the unrepresentative Barre government and to gain independence for Somaliland from the rest of Somalia. ${ }^{40}$ This also created a cycle of violence between clans. The collapse of the Siad Barre government in January 1991 also seemed to act as trigger for the country's current piracy problem. ${ }^{41}$

The Provisional Irish Republican Army

The Provisional Irish Republican Army (IRA) carried out several terrorist attacks against maritime targets in the 1970s. The first incident of this nature occurred in February 1972 when a bomb was found on the passenger ferry, Duke of Argyle. ${ }^{42}$ Another incident, the assassination of Lord Mountbatten and his family on board the family pleasure boat, Shadow $V$, in Mullaghmore harbour, County Donegal, was the only incident that received lasting publicity. ${ }^{43}$ The IRA also used ships to smuggle weapons. On 28 March 1973, the Cypriot coaster, Claudia, with Joe Cahill, a former commander of the Provisional IRA, on board, was intercepted when an attempt was made to offload weapons on the Irish coast. Five tons of weapons supplied by Colonel Gadaffi were confiscated. ${ }^{44}$

Maritime Terrorism in the Caribbean and Americas

In the Americas, maritime terrorism occurred as a result of the US-Cuban conflict, as well as efforts to damage the Nicaraguan economy. Between 1960 and 1977, anti-Castro Cuban exile groups were responsible for more than 25 maritime terrorist attacks. After the Bay of Pigs incident in 1961, terrorist groups such as Alpha 66, the Second Front and Commandos L, were unable to operate on Cuban territory and therefore turned to maritime terrorism, which was financially supported by the US and Cuban exile community. These groups were armed and trained in navigation and underwater demolitions by the Central Intelligence Agency (CIA), and until 1968, they were responsible for attacks against Cuban ports and Soviet ships in the Caribbean. Groups such as Commandos L were also equipped with fast boats armed with $57 \mathrm{~mm}$ recoilless rifles and machine guns. In 1960, a French freighter offloading explosives in Havana was blown up. This attack was attributed to sabotage by anti-Castro groups. ${ }^{45}$ During such an attack in April 1963, Commando L launched a hit-and-run attack on a Russian freighter in the Cuban port of Isabella de Sagua, severely damaging the ship. ${ }^{46}$ 
Attacks were also carried out on Cuban ships and ships trading with Cuba in US harbours and territorial waters. In 1968, the US Coast Guard foiled an attempted attack on a Cuban merchant ship. In the same year, British, Japanese and Polish ships allegedly trading with Cuba were damaged by explosive devices in US harbours. One of these was the British freighter Caribbean Venture, which was damaged by an underwater explosion while at anchor in Biscayne Bay, Miami, Florida. The Cuban exile group El Poder Cubano claimed responsibility. ${ }^{47}$

Between 1983 and 1985, anti-Sandinista forces in countries bordering Nicaragua aiming to damage the Nicaraguan economy were responsible for 13 maritime terrorist attacks. During most of the incidents, ships detonated mines outside Nicaraguan ports. The Nicaraguan government blamed the CIA for involvement in the mining campaign, and took the issue to the International Court of Justice in The Hague. ${ }^{48}$

Prior to 2000, incidents of maritime terrorism were higher, especially in the second half of the $20^{\text {th }}$ century, compared to maritime terrorist incidents between 2000 and 2011. The attacks on the USS Cole in 2000, the Limburg in 2002 and the 9/11 attack in the US in 2001 created fear of a potential catastrophic terrorist attack in the maritime domain. As a result of these attacks and an all-time high in incidents of maritime piracy and armed robbery of ships in 2000, maritime piracy and terrorism were increasingly linked and became highly controversial subjects.

\section{Twenty-First Century Extent, Causes and Consequences of Piracy and Armed Robbery of Ships}

Several socio-economic and political factors contribute to maritime piracy and acts of armed robbery of ships, such as underdevelopment and political instability, criminality and corruption, and ineffective government and law enforcement agencies. ${ }^{49}$ Small and inadequate navies and coast guards also contribute to the existence of piracy and armed robbery of ships, especially if there is a lack of will to act on reported incidents. ${ }^{50}$ The lenient sentences that pirates and maritime criminals receive when apprehended, the lucrative nature of the crime, the cost of defence mechanisms to shipping companies and vessel owners, and the lack of international and regional co-operation in the conviction of pirates all contribute to these crimes. Geography also has an impact on maritime attacks. Islands provide concealment for pirates and slow vessels down, making them more vulnerable to attacks. 
Between $2000^{51}$ and end of May $2013,{ }^{52}$ a total of 4759 incidents of piracy and acts of armed robbery of ships occurred worldwide. Although there was a sharp increase in incidents (attempted and actual attacks) in Somalia in 2009, the number of successful hijackings of ships remained constant and attacks were proportionally less successful, which could be attributed to the presence of a foreign navy in these waters. ${ }^{53}$ In 2010, a ten per cent increase in piracy-related incidents was reported, which was mainly due to an increase in pirate activity in Indonesian waters. Attacks by Somalian pirates remained constant, but their success rate increased with 49 ships hijacked and 1016 crew members taken hostage. This indicated that pirates adapted to the higher foreign naval presence by expanding their area of operation more than 1000 NM from the Somali coast into the Eastern Red Sea, Oman in the Arabian Sea and the Indian Ocean as far as the Maldives. ${ }^{54}$

Somalian Pirates and Incidents of Piracy off the Somalian Coast, the Red Sea and Arabian Sea

In 2011, Somalian pirates launched 176 attacks during which 25 ships were pirated. ${ }^{55}$ A total of 75 attacks were attributed to Somalian pirates in 2012, during which 14 hijackings took place and 250 hostages were taken. Attacks were lower in 2012 due to the presence of security teams on board ships, increased ship's hardening, the efforts of naval forces in the area and land-based anti-piracy operations. ${ }^{56}$

Pirates used mother ships to launch three or four speedboats (with four to eight pirates on board) allowing them to operate further from the Somali coast and to avoid the naval deployments. At least five mother ships with speedboats in tow operated in this area and hid themselves among the many fishing vessels. During such an incident on 4 April 2008, the previously hijacked Russian trawler, $F V$ Burum Ocean, was used in an attack on the French luxury yacht Le Ponant. After the attack, the FV Burum Ocean was abandoned. In other cases, hijacked vessels are turned into mother ships if ransom demands are not met, as in the case of the MT Yenegoa Ocean hijacked on 4 August 2008. Mother ships are supplied from ports at Al Mukallah, Al Shishr, Nishtun and Al Ghaydah on the Yemeni coast, and Bossaso, Aluula and Mogadishu in Somalia. ${ }^{57}$

Maritime piracy and acts of armed robbery of ships range between opportunity theft when a ship is at berth, hit-and-run attacks mostly at night where pirates or maritime criminals rob a ship or crew, and attacks with the intent to take 
the crew hostage (worldwide 5956 crew members were taken hostage between $2003^{58}$ and $2012^{59}$ ) or to hijack the ship for ransom or mother ship services. The levels of violence and financial losses due to attacks differ according to the type of attack but also according to the geographical location where the attack occurs. Almost all attacks in Somalia, the Red Sea and the Gulf of Aden took place while vessels were cruising, and hijacking was the motive in almost all the cases. ${ }^{60}$ Pirate attacks in Somalia range from unplanned attacks to well-organised attacks with the intention to hijack the ship and to hold both ship and crew for ransom. ${ }^{61}$ Automatic weapons and rocket-propelled grenade launchers (RPGs) are used during attacks.

\section{Maritime Piracy in West Africa}

Between 2000 and 2012, Nigeria had 304 incidents of piracy and armed robbery of ships. By 2008, the second highest number of incidents of piracy and acts of armed robbery of ships worldwide was recorded on the high seas surrounding Nigeria. ${ }^{62}$ In 2011, attacks took place as far off as $120 \mathrm{NM}$ off the coast adjacent to Nigeria. ${ }^{63}$ Attacks are frequent in and around Lagos, Brass, Port Harcourt and Bonny River, where vessels are robbed and crews are kidnapped from the coast, rivers, ports and anchorages. It is estimated that only a third of incidents are recorded in this area.

Militants in the Niger Delta exist on a spectrum of purely criminal to politically orientated deeds, and in some cases, a mixture of the two in the same organisation. The most prominent of these groups, MEND, portrays itself as a resistance movement fighting for human and social rights, but the Nigerian government sees the activities of this group as purely criminal. ${ }^{64}$ MEND includes several rebel groups in the Niger Delta organised in a loose network with an estimated thousand members. It has the ability to launch attacks with hundreds of "war boats" from "bases" spread across the Niger Delta against oil flow stations, offshore facilities, gun boats and pipelines. ${ }^{65}$ Illegal oil bunkering, payments for "security" services by oil companies to militants, as well as ransom money are all used to fund more weapons in this conflict. During such an incident in October 2006, an oil vessel was attacked at Cawthorne Channel, killing five soldiers escorting the vessel and sinking the vessel.

MEND has already taken hundreds of foreigners hostage since it launched its campaign of violence in early 2006, with the objective to receive a bigger share of the oil profits. ${ }^{66}$ In 2007 alone, more than 200 oil workers were kidnapped. ${ }^{67}$ According to Shell representatives, the company recorded 150 incidents of sabotage 
and oil theft in $2006 .{ }^{68}$ Criminals have joined this trend in the delta in a number of copycat abductions of oil workers. There is also an indication that senior members of government are involved in the financial and logistical support of militant groups.

In Nigeria, 49 kidnappings of mostly oil industry workers took place in 2006 and 39 in $2008 .{ }^{69}$ An example of such a kidnapping was the attack on the Liberty Service on 11 January 2006. The vessel operated as a security vessel and had 14 Nigerian naval personnel on board. About 40 armed robbers in three motorised canoes attacked and boarded the vessel underway and kidnapped four personnel (two expatriates). This has been an ongoing trend in the area and is characterised by the apparent inability of the naval forces to bring the situation under control. ${ }^{70}$

Almost all attacks in Nigeria occur in territorial waters. Ten hijackings were attributed to Nigerian pirates in 2011 and ten in 2012, ${ }^{71}$ but it is estimated that attacks went highly underreported. Some of these hijackings occurred as far as Benin, the Ivory Coast and Togo. In 2009 and 2010, 47 attacks were reported. ${ }^{72}$ Forty attacks were reported in 2008 during which 27 vessels were boarded and five hijacked. Some vessels were taken to rebel bases. Attacks are violent and crew members are often injured. Seventeen of these attacks were against tankers and seven against support and supply ships. The remaining attacks were against bulk carriers, general cargo ships and container ships. Even ships with armed escort or security guards are attacked. In most cases, attackers use speedboats and automatic weapons. ${ }^{73}$

The fishing industry is also affected by armed robbery of ships. According to the Nigeria Trawlers Owners Association, attacks lead to loss of life, income and equipment. The worst affected regions are Forcados, Burutu, Akwa-Ibom, the Badagry Estuary and the Bakassi Peninsula. ${ }^{74}$

In 2011, 20 highly organised attacks were reported on tankers off the coast of Benin of which five were hijackings with the objective to steal equipment and cargo. It is probable that these attacks were executed by Nigerian pirates. Attacks are often violent, but captivity is usually brief (average of 10 days). During one such an attack on 3 March 2011, the chemical tanker MT Duzgit Venture was attacked and hijacked 12.5 NM off Cotonou, Benin. The pirates ordered the master to sail to Gabon. On arriving, it was discovered that the bunkers were not enough. They sailed $60 \mathrm{NM}$ off the coast to wait for a bunker vessel to transfer the oil to, which did not arrive. Then they sailed to Lagos, Nigeria and contacted a few fast boats. They 
abandoned the plan to steal the cargo and instead stole the crew's belongings and took the master and two crew members hostage. They were released later. ${ }^{75}$

\section{Maritime Terrorism in the Twenty-First Century}

No exclusively maritime terrorist organisations exist today. Maritime terrorism is only one of the areas of operation for terrorist organisations. With the exception of Sri Lanka, acts of maritime terrorism have been limited compared to acts on land. In Sri Lanka, the Liberation Tigers of Tamil Eelam (LTTE) and its maritime wing, the Sea Tigers, comprising 4000 seamen, is the organisation with the most advanced maritime capabilities. During their struggle for independence, the Sea Tigers destroyed one third of the Sri Lankan Navy fleet. ${ }^{76}$ Only a few actual proven cases of maritime terrorism occurred in the last 30 years (two per cent of all global incidents in the last 30 years were seaborne terrorist strikes). ${ }^{77}$ Even though few maritime terrorism attacks occurred after 2000, the 9/11 incident underlined the potential danger of such attacks. In January 2000, Al Qaeda's affiliate, the AdenAbyan Islamic Army (AAIA), implemented a new strategy to attack high-profile US targets including maritime targets. Boats loaded with explosives could be remotely detonated or used as suicide weapons by ramming other vessels. Such an attack on the USS Sullivan in January 2000 failed when the suicide boat, overloaded with explosives, sank in the Port of Aden. ${ }^{78}$

In October 2000, two terrorists linked to Al Qaeda used a modified dinghy packed with approximately $230 \mathrm{~kg}$ ) of C-4 explosives to blow a hole in the US destroyer, USS Cole, while in the Port of Aden, Yemen. Seventeen sailors were killed and 40 wounded, with estimated damages of US\$250 million to the ship. ${ }^{79}$ Six men, all of whom fought in Afghanistan against the Soviets, were arrested for the attack. Intelligence gained from this arrest led to a missile attack by the US on 5 November 2002 from a Predator unmanned aerial vehicle (UAV) on a vehicle driven by Al Qaeda operatives. Among them was Qaed Salim Siman al-Harethi, a high-ranking operator who took part in the attack on the Cole. ${ }^{80}$

In October 2002, the French-registered oil tanker, Limburg, carrying crude oil off the coast of Yemen was bombed using a small boat loaded with explosives. Ninety thousand barrels of oil spilled into the Gulf of Aden leading to huge financial losses for Yemen in the form of tourist cancellations, cost of cleaning-up operations and consequent limited use of the port. ${ }^{81}$ This incident led to counter-terrorism cooperation with the US government and British Special Forces. Mosques and Islamic organisations were monitored, illegal immigrants and suspected terrorists 
were deported and a public awareness campaign was launched to inform Yemenis of the cost of terrorism to their economy. ${ }^{82}$ This also led to the forming and training of a coast guard with US assistance. ${ }^{83}$

In 2004, the Abu Sayyaf Group (ASG) bombed Philippine Superferry 14 carrying 899 passengers, ${ }^{84}$ by placing a bomb in a television set, killing more than a hundred people. The ferry company, Sulpicio and William, Gothong and Aboitiz (WG\&A) lines, received an extortion letter prior to the bombing, demanding one million dollars for the safe use of the waters of Mindanao. ${ }^{85}$

Attacks at sea are not simple operations and hold their own difficulties.Concealment during surveillance at sea offers more problems than on land. There are various variables to take into account when planning an attack at sea, such as tides, currents, wind, storms, visibility and proximity to land. Expert skills in boat handling and navigation are required. Preparing and practicing for an attack as well as testing weapons are more problematic at sea than on land. ${ }^{86}$ Land and air attacks provide greater publicity for terrorists than attacks at sea. The comparatively slow progress of a ship provides reaction time for a victim country to react to potential terrorist attacks and time for the crew to warn shore-based authorities. ${ }^{87}$ Escaping after an act of terrorism at sea is more difficult than on land as it is often not easy to hide or disappear in the open ocean especially when governments make use of technology such as radar and air support. For acts of economic terrorism, with the purpose of disrupting the world economy or the economy of a specific country, the sea provides greater scope for terrorism because more merchandise is moved by sea than by air. ${ }^{88}$

Attacks on some maritime terrorist targets could potentially be very damaging to human life and the environment and could lead to high financial losses. Such potential targets are "chokepoints", global container trans-shipment hub ports, world oil supply lines, cruise ships and passenger ferries. "Chokepoints" are narrow straits through which vessels are forced to travel, such as the Malacca and Singapore Straits and the Suez Canal. The closure of a hub port housing container transshipment facilities such as Singapore, Hong Kong and Rotterdam could lead to the loss of millions of dollars a day, and an attack on such a port could lead to high losses in terms of human life. ${ }^{89}$

The fear exists that terrorists could deliver a nuclear, chemical, biological or radiological device, weapon or substance to a target destination through the use of 
cargo containers. Explosives on a ship or smaller boat could also be remotely detonated or used as a suicide weapon by ramming another vessel.

There are more differences between maritime terrorism and piracy than similarities, mainly because the objectives and tactics of these groups differ.

\section{Resemblances and Differences between Maritime Terrorism and Piracy}

It is important to distinguish between piracy and maritime terrorism in order to establish effective policies and counter-measures. ${ }^{90}$ Motives or aim, preferred targets, tactics and operational reach, are all factors where distinctions and similarities between pirates and terrorists could be noted. Probably the best distinction between pirates and terrorists is their motives, mostly financial in the case of pirates and political where terrorists are concerned. In several cases, these distinctions become blurred as in the case of MEND in the Niger Delta, Nigeria, where kidnappings of oil workers had both a financial and political motive. ${ }^{91}$ This also became true in Somalia in April 2011 with the release of the MV Asphalt Venture. After a multi-million dollar ransom was paid, the pirates double-crossed the ship owners and refused to release seven of the original crew. They demanded the release of the 100 pirates that the Indian navy captured in preceding months in return for the safe return of the seven hostages. ${ }^{92}$

As pirates' motives are financial, it will affect the choice of target. Targets are chosen for their value and vulnerability. Vessels that are easy to board with a small crew will be a preferred target. Terrorists choose vessels with a symbolic value, where casualties might be higher or for the vessel's potential use as a weapon. ${ }^{93}$ Another distinction is the use of violence. In most cases, pirates try to prevent loss of life for fear of retaliation by foreign navies. Currently, foreign navies in Somalia do not interfere with ships once they have been pirated because of the risk piracy holds to human life. The opposite is true for terrorists where publicity usually increases with greater loss of human life.

Pirates make use of simple tactics, while terrorists use more sophisticated tactics. Piracy also takes place at local or regional level, while terrorists can have a more global reach in terms of objectives. There are, however, terrorist groups that operate only at local or regional level and aim to fulfil political agendas at local level, such as the LTTE, Gerakan Aceh Merdeka (GAM) and ASG. ${ }^{94}$ Pirates would also normally try to avoid attention, while terrorists seek attention to promote their cause. 
A few similarities between pirates and maritime terrorists also exist. Both pirates and maritime terrorists operate in the maritime environment using ships or boats and must have the skills to operate such vessels. In addition, their actions are planned rather than impulsive. In both cases, actions are mostly aimed at civilians and have a human cost attached to operations, and both groups can operate across borders. ${ }^{95}$ Small, fast boats are often chosen for operations for their speed, manoeuvrability, effectiveness to evade radar detection and because they are less expensive to acquire and maintain than large vessels. Both groups also need a land base from which to operate. Pirates and maritime terrorists both become more effective as they get more organised and both make use of intelligence to plan actions. Violence or the threat of violence is also utilised by both groups. Pirates as well as terrorist organisations need funds to sustain their operations. ${ }^{96}$ Both pirates and terrorists will also have an effect on the socio-economic and political security in the areas where they operate. ${ }^{97}$

Certain conditions also favour both maritime terrorists and pirates, creating an environment where piracy and terrorism can flourish. These are legal and jurisdictional weaknesses in the country where these incidents occur, geography, inadequate security and weak and under-funded law enforcement, the potential for reward, and a favourable political environment due to a weak or corrupt government or the lack of political will to act on security threats. ${ }^{98}$ The geography of Southeast Asia is a major factor influencing maritime terrorism, piracy and acts of armed robbery of ships. Narrow channels which slow traffic down, thousands of islands that provide shelter ${ }^{99}$ and thousands of kilometres of coastline are all to the advantage of pirates, armed robbers and terrorists during attacks. ${ }^{100}$ The proximity of different countries and overlapping jurisdictions also make it easy for boats to move from the coastal waters from one country to those of another, which creates problems for law-enforcing agencies. It is therefore difficult for countries to adhere to and enforce rigid boundaries. ${ }^{101}$

Similarities between pirate groups and maritime terrorist organisations should however not be confused with connections between the two, but there have been cases where maritime terrorists used piracy to further their objectives. Terrorists could use a hijacked ship to launch a suicide attack on another ship or a port. This option could be especially viable if there are hostages involved. Hijacked ships could be used to smuggle weapons or explosives or to procure ransom to fund operations. Smuggling is a safer undertaking with hostages on board. Crew could also be used in a hostage situation to exchange for members of the terrorist group in 
detention. ${ }^{102}$ Proven cases where terrorists collaborate with pirates do not exist to date however.

Limited connections between maritime terrorism and incidents of maritime piracy and armed robbery of ships could be found. In the 1970s, several maritime incidents involving hostage taking and hijacking by the Moro National Liberation Front (MNLF) in the Philippines were reported. Since 2000, several incidents of armed robbery of ships were also linked to the Moro Islamic Liberation Front (MILF) or elements within the organisation. Since 2001, 37 piracy cases in the Philippines were attributed to rebel groups. ${ }^{103}$

In some cases, maritime terrorists are credited for pirate attacks, a notion which does not always have a foundation. Several publications used the hijacking of the Dewi Madrim in the Malacca Straits in March 2003 as example to establish a link between piracy and maritime terrorism. It was reported that the Dewi Madrim was hijacked by terrorists learning to steer a ship, and that the crew was kidnapped as a practice run for future maritime terrorist attacks. The source of the initial report was a private security company, Aegis Defence Services Limited. The IMB denied that terrorists were involved in this attack, that pirates made any attempt to steer the vessel, or that anyone was kidnapped during this incident. Aegis claims that they were misquoted in the press. ${ }^{104}$

Claims by the Indonesian government that GAM is involved in piracy attacks may well be over-exaggerated to discredit the organisation. Some involvement could however be attributed to the organisation or criminal elements within the organisation. ${ }^{105}$

In recent years, conflicting reports were received concerning cooperation between pirate groups and Harakat al-Shabaab al-Mujahideen or the Mujahideen Youth Movement (Al-Shabaab), an Islamic organisation, with its roots in the youth movement of the Islamic Courts Union in Somalia. Al-Shabaab is in control of a large part of Somalia. In February 2012, the leader of Al-Shabaab, Ahmed Abdi Godane (alias Mukhtaar Abuu Zubeyr) formally affiliated the organisation with AlQaeda. Godane has aspirations to be the leader of Al-Qaeda in East Africa. His aspirations became a possibility with the death of Bin Laden in May 2011. Bin Laden did not trust Godane because he feared that Godane was interested in local political aspirations and not global jihad. This formal alliance with Al-Qaeda brought a division in the leadership structure of Al-Shabaab between Godane and two senior commanders: Sheikh Hassan Dahir Aweys, who is a more moderate 
leader, and Mukhtar Robow Abu Mansour. Both leaders are more interested in political ambitions to control Somalia than in a global jihad, and it was rumoured that they were willing to open dialogue with the Transitional National Government (TNG) and the international community for a possible solution in Somalia in return for certain concessions such as the withdrawal of AMISOM, the recognition of Sharia Law and amnesty for Al-Shabaab fighters, and the removal of their leaders' names from the US and UN terror list. ${ }^{106}$ The US placed a US\$33 million bounty on several Al-Shabaab leaders' heads in June 2012. ${ }^{107}$ Aweys was not on the bounty list, which caused further distrust among the leadership structure. ${ }^{108}$ Many of the AlShabaab leaders reportedly received training in Al-Qaeda camps in Afghanistan, such as Ibrahim Haji Jama, ${ }^{109}$ who is also one of the leaders featured on the US bounty list.

Al-Shabaab is responsible for several bombings in Somalia as well as in Uganda. ${ }^{110}$ In some instances, it was reported that pirates based at Harardhere relocated to the port town of Hobyo in April 2010 as Al-Shabaab fighters advanced on Harardhere. ${ }^{111}$ Similar reports were received in 2011, in which it was stated that 50 pirates were captured by the movement in Harardhere when negotiations over a percentage of the ransom money failed. ${ }^{112}$ It was reported that Al-Shabaab could be targeting Harardhere because pirates disrupted the organisation's coal exports operating from Kismayo, when the pirates hijacked nine Indian-owned dhows (sailing vessels). Al-Shabaab generates income from these exports as well as from taxes levied on the use of the harbour. ${ }^{113}$

Other reports stated that Al-Shabaab provides weapons and trains pirates in return for a percentage of the ransom money received from hijackings, which is used as a source of funding for this organisation. It would not be to pirates' advantage to collaborate with Al-Shabaab for fear of retaliation from countries such as the US. It is in their interest to keep the status quo in terms of foreign navies, which do not interfere with pirated ships as long as there is no loss of life, in which case the pirates also continue to receive ransom for the safe release of ships. It is however possible that protection money could be extorted from pirate groups by both Islamic organisations as well as government forces. It is not an impossible scenario that AlShabaab could launch maritime attacks against Western targets especially when prior attacks on international targets, such as aid workers and peacekeepers, are taken into account, as well as in retaliation for US attacks on Al-Shabaab leaders, such as the attacks on Aden Hashi Ayro in May 2008 and Saleh Ali Saleh Nabhan in September 2009. ${ }^{114}$ 
Terrorist organisations can benefit from collaboration with pirate groups through the transference of skills and experience. Pirate groups can benefit through the acquisition of arms and supplies as terrorist organisations already have these networks in place. ${ }^{115}$ A problem that navies face in dealing with hijackings of ships in vulnerable areas such as in chokepoints or close to hub ports, is that it is virtually impossible to know whether the vessel is under pirate command with ransom as objective, or whether terrorists are in command with potentially devastating results. It would, therefore, be wise to treat any such attack as a potential terrorist attack, until otherwise proven. ${ }^{116}$

\section{Conclusion}

Piracy is a dangerous threat to international maritime trade, especially in the area off the Somalian coast, the southern Red Sea, the Gulf of Aden as well as the Arabian Sea. During 2010 and 2011, incidents also increased in Indonesian and West African waters. In contrast, over the last ten years, incidents of maritime terrorism have been lower than before but, due to the 9/11 incident in the US and the rise of more spectacular forms of terrorist acts, the fear exists that a captured ship could be used as a delivery platform for WMD or that a ship with dangerous cargo itself could be used as a weapon. The impact of such an attack on the world economy and the environment could be catastrophic, especially if world hub ports or chokepoints were targeted.

As pirates and terrorist ultimately operate from a host country, the socioeconomic and political climate in the host country would influence their operations. Weak legal and jurisdictional systems and a favourable political environment in the host country will benefit both groups. Although actions of pirates could have an influence on world trade, they operate on local scale, while many terrorist organisations intentionally operate on a global scale. Loss of life is not to pirates' advantage, as they fear retaliation and possible legal consequences of such action, while for terrorists such actions create more publicity. Pirates also fear loss of their own lives, while in recent years, terrorist attacks have often been suicide attacks.

The likelihood of pirates and terrorists working together is limited, as the objectives of pirates and maritime terrorists differ. It is not in pirates' best interest to cooperate or collaborate with terrorists. The two groups, however, often use the same tactics, of which hijacking is the most common. The use of a hijacked ship to launch a terrorist attack could become more viable when hostages are held on board in order to prevent navies from taking action against the pirates. It is also difficult to 
be certain when a hijacking occurs, that it is in fact a case of piracy and not a possible terrorist attack. Attention should be paid to deviations in pirate tactics or geographical operational areas in order to detect any potential terrorist attacks to take timely preventative measures. The most dangerous situation is probably not the collaboration of pirates and terrorists, but when a terrorist attack is mistakenly identified as a piracy incident, as the consequences and preventative measures relating to these two situations will differ considerably.

\section{Endnotes}

${ }^{1}$ Based on a master's dissertation completed in 2011 in the Department of Political Sciences, University of Pretoria, under supervision of Prof. M. Hough.

${ }^{2}$ Chalk, P, Greenberg, MD, Khilko, I, Ortiz, DS \& Willis, HH. Maritime terrorism: Risk and liability. Santa Monica, CA: RAND Centre for Terrorism Risk Management Policy, 2006.

${ }^{3}$ United Nations. "Convention on the Law of the Sea". 1982. < http://www.un.org/Depts/los/convention_agreements/texts/unclos/closindx.ht $\underline{m}>$ Accessed on 10 May 2006.

${ }^{4}$ Johnson, D, Pladdet, E \& Valencia. M . "Introduction. Research on Southeast Asian Piracy", in Johnson, D \& Valencia. M (eds), Piracy in Southeast Asia: Status, issues, and responses, Singapore: Institute of Southeast Asian Studies, 2005.

5 International Maritime Organization. "Code of Practice for the Investigation of Crimes of Piracy and Armed Robbery against Ships Resolution A.1025(26). 2 December 2009.

http://www.imo.org/OurWork/Security/PiracyArmedRobbery/Guidance/Doc uments/A.1025.pdf. Accessed on 8 July 2012.

${ }^{6}$ Ranstorp, M \& Wilkinson, P. "Terrorism and political violence”. Paper presented at the International Conference on Terrorism and Human Rights, 13-15 July 2003. In Terrorism and Political Violence, Vol. 17, 2005.

${ }^{7}$ Johnson \& Valencia op. cit.

${ }^{8}$ Ibid.

${ }^{9}$ International Chamber of Commerce, International Maritime Bureau. Piracy and armed robbery against ships: Annual report. London, 1 January - 31 December 2006.

${ }^{10}$ International Maritime Organization. "Focus on IMO: Piracy and armed robbery at sea". January 2000. < http://www.imo.org/includes/blast_bindoc.asp?doc_id=433\&format=PDF $>$ Accessed on 29 August 2005.

${ }^{11}$ International Chamber of Commerce, International Maritime Bureau. Piracy and armed robbery against ships: Annual report. Essex, 1 January - 31 December 2005.

${ }^{12}$ Frécon, E. "The resurgence of sea piracy in Southeast Asia". Occasional Paper No. 5. Bangkok: Research Institute on Contemporary Southeast Asia, 2008. 
${ }^{13}$ Memorial Institute for the Prevention of Terrorism (MIPT) Knowledge Base. "Memorial Institute for the Prevention of Terrorism". <www.mipt.org> Accessed on 23 June 2008.

${ }^{14}$ International Maritime Organization op. cit.

${ }^{15}$ Ellen, E. "Piracy". In Ellen, EF (ed.), Violence at sea: A review of terrorism, acts of war and piracy and counter measures to prevent terrorism, Paris: International Chamber of Commerce International Maritime Bureau, 1987.

${ }^{16}$ Ellen, E. "Bringing piracy to account". Jane's Navy International. April 1997.

${ }^{17}$ Ellen, "Piracy" op. cit.

${ }^{18}$ International Maritime Organization op. cit.

${ }^{19}$ Agbakoba, EG. "The fight against piracy and armed robbery against ships. 2004. < http://home.wanadoo.nl/m.bruyneel/archive/modern/imopirac.htm > Accessed on 3 December 2004.

${ }^{20}$ Hyslop, IR. “Contemporary piracy”. In Ellen, E (ed.), Piracy at sea, Paris: International Chamber of Commerce Publishing, 1989.

${ }^{21}$ Office of the Defence Attaché, Permanent Mission of Nigeria to the United Nations. "Piracy control in Nigeria's territorial seas". In Ellen, Piracy at sea op. cit.

${ }^{22}$ Agbakoba op. cit.

${ }^{23}$ Maritime Security Council. “Anti-Shipping Activity Messages (ASAM)”. 19891999. < http://www.fas.org/irp/world/para/docs/ASAM-1988.htm> Accessed on 3 December 2004.

${ }^{24}$ Ibid.

${ }^{25}$ Menefee, SP. “The United States and post-war piracy”. In Ellen, Piracy at sea op. cit.

${ }^{26}$ Hyslop op. cit.

${ }^{27}$ Murphy op. cit.

${ }^{28}$ Menefee op. cit.

${ }^{29}$ Birnie, PW. "Piracy: Past, present and future". In Ellen, Piracy at sea op. cit.

${ }^{30}$ Peres, LMS. "Henrique Galvặo, 1895-1970: Aspects of a Euro-African crusade". University of South Africa. March 2009. < http://uir.unisa.ac.za/bitstream/handle/10500/3153/dissertation_peres_.pdf?s

${ }^{31}$ Birnie op. cit. equence=1> Accessed on 26 July 2012.

${ }^{32}$ Brittin, BH. "The law of piracy: Does it meet the present and potential challenges? In Ellen, Piracy at sea op. cit.

${ }^{33}$ Schiller, TS. "Maritime terrorism: The threat". In Ellen, Violence at sea ... op. cit.

${ }^{34}$ Bohn, MK. The Achille Lauro Hijacking. Washington, DC: Potomac Books, 2004.

${ }^{35}$ Simon, JD. "The implications of the Achille Lauro Hijacking for the maritime community". In Ellen, Violence at sea ... op. cit.

${ }^{36}$ Simon op. cit.

${ }^{37}$ Bohn op. cit.

${ }^{38}$ International Maritime Organization. "Convention for the Suppression of Unlawful Acts against the Safety of Maritime Navigation 1988”. 2005. < 
http://www.imo.org/About/Conventions/ListOfConventions/Pages/SUA-

Treaties.aspx. Accessed on 11 May 2006.

${ }^{39}$ Schiller op. cit.

${ }^{40}$ Maritime Security Council op. cit.

${ }^{41}$ Murphy op. cit.

${ }^{42}$ Schiller op. cit.

${ }^{43}$ Ellen, "Piracy" op. cit.

${ }^{44}$ Wilkinson, P. "Terrorism and the maritime environment". In Ellen, Violence at sea ... op. cit.

${ }^{45}$ Cordes, B, Gardela, K. Jenkins, BM \& Petty, G. "A chronology of terrorist attacks and other criminal actions against maritime targets". In Ellen, Violence at sea. op. cit.

${ }^{46}$ Nendrix, H. "Raiders damage red ship". The Miami News. 5 April 1963. <www.latinamericanstudies.org/belligerence/sagua.htm $>$ Accessed on 15 July 2012.

${ }^{47}$ Jenkins op. cit.

${ }^{48}$ Boulanger, P. "The Gulf of Thailand". In Ellen, Piracy at sea ... op. cit.

${ }^{49}$ International Maritime Organization op cit.

${ }^{50}$ McDaniel, MS. "Modern high seas piracy". The Law Offices of Countryman \& McDaniel. 20 November 2000. <www.cargolaw.com /presentations_pirates.html > Accessed on 12 March 2004.

${ }^{51}$ International Chamber of Commerce, International Maritime Bureau. Piracy and armed robbery against ships: Annual report. London, 1 January 2000 - 31 December 2011.

${ }^{52}$ International Chamber of Commerce, International Maritime Bureau. "Piracy news and figures". <www. icc-ccs.org/piracy-reportingcentre/piracynewsafigures > Accessed on_8 July 2012.

${ }^{53}$ International Chamber of Commerce, International Maritime Bureau. "Pirates intensify attacks in New Areas, with first Somali hijacking reported in Red Sea". 18 October 2010. <www. icc-ccs.org/news/315-pirates-intensifyattacks-in-new-areas-with-first-somali-hijacking-reported-in-red-sea > Accessed on 18 October 2010.

${ }^{54}$ International Chamber of Commerce, 2010, op, cit.

${ }^{55}$ International Chamber of Commerce, 2011, op. cit.

${ }^{56}$ International Chamber of Commerce, International Maritime Bureau. Piracy and armed robbery against ships: Annual report. London, 1 January - 31 December 2012.

${ }^{57}$ UN Security Council. "Report of the Monitoring Group on Somalia pursuant to Security Council Resolution 1811 (2008). S/2008/769”. 20 November 2008. < http://www.securitycouncilreport.org/atf/cf/\%7B65BFCF9B-6D27-4E9C8CD3-CF6E4FF96FF9\%7D/Somalia\%20S2008\%20769.pdf> Accessed on 14 April 2009. 
${ }^{58}$ International Chamber of Commerce, International Maritime Bureau. Piracy and armed robbery against ships: Annual report. London, 1 January - 31

December 2008.

${ }^{59}$ International Chamber of Commerce, 2011, op. cit.

${ }^{60}$ International Chamber of Commerce, 2005, op. cit.

${ }^{61}$ UN Security Council op. cit.

${ }^{62}$ International Chamber of Commerce, 2008, op. cit.

${ }^{63}$ International Chamber of Commerce, 2011, op. cit.

${ }^{64}$ Chalk, P, Long, A, McPherson, R, Parker, M \& Rosenau, W. Corporations and counterinsurgency. Santa Monica: RAND National Security Research Division, 2009.

${ }^{65}$ Amaize, E \& Onyoyume, J. "MEND declares 'Oil War"'. Vanguard. 15 September 2008.

66 "MEND releases photos of British hostages". This Day. 12 January 2009.

${ }^{67}$ Chalk et al. op. cit.

${ }^{68}$ Amzat, A. "Shell, Chevron, others blame government over Delta Crisis". The Guardian. 2 October 2007.

${ }^{69}$ International Chamber of Commerce, 2008, op. cit.

${ }^{70}$ International Chamber of Commerce, 2006, op. cit.

${ }^{71}$ International Chamber of Commerce, 2012, op. cit.

${ }^{72}$ International Chamber of Commerce, 2010, op. cit.

${ }^{73}$ International Chamber of Commerce, 2008, op. cit.

${ }^{74}$ Okere, R. "Pirates wreak havoc on waterways". Guardian. 12 September 2005.

75 Ibid.

${ }^{76}$ Nelson, ES. "Maritime terrorism and piracy: Existing and potential threats". Global Security Studies. 3/3. Winter 2012.

<www.Globalsecuritystudies.com/Nelson Piracy Final.pdf > Accessed on 11 July 2012.

${ }^{77}$ Greenberg et al. op. cit.

${ }^{78}$ Schanzer, J. "Yemen's war on terror". Orbis. Summer 2004. < http://humansecuritygateway.com/documents/WINEP_YemensWarOnTerro r.pdf > Accessed on 30 July 2009.

${ }^{79}$ Richardson, M. “A Time Bomb for Global Trade: Maritime Related Terrorism in an Age of Weapons of Mass Destruction". Institute of Southeast Asian Studies. Singapore. 2004.

${ }^{80}$ Schanzer $o p$. cit.

${ }^{81}$ Richardson op. cit.

${ }^{82}$ Schanzer op. cit.

${ }^{83}$ Lackey, SA. "Yemen after the cole". Sea Power. 48/3. March 2005. <http://0search.epnet.com.innopac.up.ac.za> Accessed on 23 May 2006.

${ }^{84}$ Banlaoi, RC. "Maritime terrorism in Southeast Asia: The Abu Sayyaf threat". Naval War College Review. 58/4. Autumn 2005.

${ }^{85}$ Greenberg et al. op. cit. 
${ }^{86}$ United States Congressional Research Service. Maritime security: Potential terrorist attacks and protection priorities. 9 January 2007.

${ }^{87}$ Nadkarni, JG. "A coalition at sea". 15 November 2001. 〈http://www.rediff.com> Accessed on 12 April 2004.

${ }^{88}$ Raman, B. "Maritime terrorism: An Indian perspective". South Asia Analysis Group, Paper no 1154. New Delhi, 29 October 2004.

${ }^{89}$ Richardson op. cit.

${ }^{90}$ Nelson op. cit.

${ }^{91}$ Chew, F. "Piracy, maritime terrorism and regional interests". Geddes Papers, Australian Defence College. 2005.

<www.defence.gov.au/adc/docs/publications2010/PublcnsGeddes2005_310 310_PiracyMaritime.pdf> Accessed on 22 June 2010.

92 NDTV. "7-month-ordeal over, MV Asphalt venture crew returns home". 1 May 2011. <www.ndtv.com> Accessed on 1 June 2011.

${ }^{93}$ Nelson op. cit.

${ }^{94}$ Chew op. cit.

${ }^{95}$ Ong, GG. "Ships can be dangerous, too: Coupling piracy and terrorism in Southeast Asia's maritime security framework. In Johnson \& Valencia op. cit.

${ }^{96}$ Nelson op. cit.

${ }^{97}$ Murphy op. cit.

98 Ibid.

${ }^{99}$ Frécon op. cit.

${ }^{100}$ Santos, EMR. "Piracy and armed robbery against ships in the Philippines". In Ong-Webb, GG (ed.), Piracy, maritime terrorism and securing the Malacca Straits, Singapore: Institute of Southeast Asian Studies, 2006.

${ }^{101}$ Young, AJ. "Roots of contemporary maritime piracy in Southeast Asia". In Johnson \& Valencia op. cit.

102 Ong-Webb op. cit.

${ }^{103}$ Santos op. cit.

${ }^{104}$ Liss, C. "Private military and security companies in the fight against piracy in Southeast Asia" In Ong-Webb op. cit.

105 Amirell, SE. "Political piracy and maritime terrorism". In Ong-Webb op. cit.

${ }^{106}$ Aynte, A. "Understanding the Al-Shabaab/Al-Qaeda 'merger'”. African Arguments. Royal African Society. 19 March 2012. <africanarguments.com> Accessed on 15 July 2012.

${ }^{107}$ BBC News. "Al-Shabab: US puts bounty on Somali militants". 7 June 2012 . < http://www.bbc.co.uk/news/world-africa-18353329 > Accessed on 15 July 2012.

${ }^{108}$ Nuxurkey, M. "Why isn't Sheikh Aweys on US Terror List?” Somalia Report. <www.somaliareport.com/index.php/post/3431 > Accessed on 15 July 2012.

${ }^{109}$ Swart, G. "Pirates of Africa's Somali coast: On terrorism's brink?" Scientia Militaria 37/2. 2009. 
${ }^{110}$ Hanson, S. “Al-Shabaab”. Council on Foreign Relations. 28 July 2010. <www.CFR.org/somalia/al-shabaab/p18650 > Accessed on 2 November 2010.

${ }^{111} \mathrm{CNN}$. "Al-Shabab is now fighting pirates and government". 26 April 2010. http://www.cnn.com/2010/WORLD/africa/04/25/somalia.pirates/index.html

112 Ahmed, M \& Sheikh, A. "Somali rebels detain several pirate gang leaders". Reuters. 17 February 2011. < http://ca.reuters.com/article/topNews/idCATRE71G6KN20110217 > Accessed on 25 August 2011.

${ }^{113}$ Ryu, A. "Somali pirates flee possible Al-Shabab attack". VOA News. 26 April 2010. <www.voanews.com/content/somali-pirates-flee-possible-al-shababattack-92099944/116524.html> Accessed on 24 August 2011.

114 The International Institute for Strategic Studies. "Somalia's al-Shabaab steps up attacks", Vol. 16. September 2010.

115 Nelson op cit.

${ }^{116}$ Ong-Webb op. cit. 